\title{
Influence of Additional Nutrients and Gelling Agents on in Vitro Response of Selected Indica Rice Varieties
}

\author{
Sai Krishna Repalli ${ }^{1}$, Chaitanya Kumar Geda ${ }^{1}$, N. S. N. Pradhan ${ }^{1}$, \& G. J. N. Rao ${ }^{1}$ \\ ${ }^{1}$ Division of Crop Improvement, ICAR- National Rice Research Institute, Cuttack, Odisha, India \\ Correspondence: Sai Krishna Repalli, Division of Crop Improvement, ICAR- National Rice Research Institute, \\ Cuttack, Odisha, India. Tel: 99-3899-6514. E-mail: saikrishnarepalli@gmail.com
}

Received: June 17, 2019

Accepted: July 8, 2019

Online Published: July 12, 2019

doi:10.5539/ijb.v11n4p26

URL: https://doi.org/10.5539/ijb.v11n4p26

\begin{abstract}
Indica rice varieties are recalcitrant to culture and hence the culture media should be supplemented with additional nutrients to provide energy and osmotic potential for best in vitro response. Combinations of plant growth regulators have profound influence on callus induction and regeneration potential of the selected genotypes. In addition, concentration and choice of gelling agents also have their effect on regeneration of indica rice varieties. Impact of L-Proline, and Casein Hydrolysate on tissue culture response of selected indica rice varieties is discussed and the best choice of gelling agent and their in vitro response is elucidated.
\end{abstract}

Keywords: Casein Hydrolysate, Gelling Agents, Indica Rice, L-Proline, Plant Growth Regulators, in Vitro Response

\section{Introduction}

Despite of the recalcitrant nature of the rice genotypes (Thokozani et al., 2013), efforts are being made by various research groups to improve the rice tissue culture protocols (Aldemita \& Hodges, 1996; Cho et al., 2004; Afolabi et al., 2008). Variations in genotypic potential and differences in growth pattern of various explants are the main reasons for the continued efforts of the rice researchers (Saharan et al., 2004; Islam et al., 2005; Khaleda \& AlForkan, 2006; Zuraida et al., 2010; Islam et al., 2014). Considering the fact that genotypic differences do exist in indica rice varieties (Yinxia \& Te-chato, 2012), other endogenous factors (Haque et al., 2003) like improving the media strength by utilization of additional nutrients (Din et al., 2016), combination of various Plant Growth Regulators (PGRs) and utilization of proper gelling agents to support the medium are given key importance in this investigation to study in vitro response of selected indica rice varieties (Pawar et al., 2015).

Callus which leads to organic regeneration and differentiation are called as embryogenic callus (Ikeuchi et al., 2013; Benlioglu et al., 2015). Moreover, management of pre and post transformants is quite essential to achieve successful events in transgenic experiments (Visarada \& Sarma, 2002; Abiri et al., 2015). Artificial culture medium is not autotrophic hence energy, osmotic potential and carbohydrate source should be supplied to the medium (Yaseen et al., 2013). Growth, development and morphogenesis of cells and tissues in vitro is maintained by proper composition of mineral nutrients (Sivanesan \& Park, 2014).

Additional nutrient supplements like L-Proline and Casein Hydrolysate $(\mathrm{CH})$ have reported to increase callus induction (Lin \& Zhang, 2005). Proline is an $\alpha$-amino acid that is essential for embryogenic callus formation, growth, and primary metabolism (Szabados \& Savoure, 2010; Che Radziah et al., 2012; Pawar et al., 2015). In the present investigation attempts were made to enrich the conventional MS media with additional nutrients like L-Proline and $\mathrm{CH}$ and the in vitro response of selected indica rice varieties was studied.

Combination of PGRs plays a pivotal role in cell growth, division and differentiation to form shoots and roots during regeneration stage (Dahot, 2007). Cytokinins decrease the apical dominance and increase adventitious shoot formation (Ngomuo \& Ndakidemi, 2013). Auxin to cytokinin ratio will help in somatic embryo development, root and shoot initiation (Azizi et al., 2015). PGRs have profound influence on somatic embryo formation. In vitro response of selected indica rice varieties under the influence of additional hormones in contrast with hormonal free medium is studied.

Gelling agents provide support for the medium and maintaining proper concentration of gelling agent is critical in supporting the growth of explants during callus induction and regeneration stages. Selected rice genotypes used in 
this study showed varied tissue culture response with respect to modern gelling agents like gelrite, clarigel and phytagel compared to conventional agar. Variations in their in vitro response were recorded and the consequences were discussed.

Tissue culture response in rice is variety specific (Khanna \& Raina, 2002; Zaidi et al., 2006; Chaitanya et al., 2013; Sai Krishna et al., 2018). The outcome of this study would help in formulating amenable media which could support the tissue culture response of most popular rice varieties, and would further help in regeneration of transformants into potential green shoots in transformation experiments.

\section{Materials and Methods}

\subsection{Genotypes}

The rice cultivars selected for the study are elite indica rice varieties Swarna, Gayatri, Samba Mahsuri, Pooja, Tapaswini, Sahabhagidhan, IR-64, Pusa Basmatil and Basmati 370. Swarna, a widely grown variety in eleven states of India, is highly popular with a yield potential of $8.0 \mathrm{t} / \mathrm{ha}$ (Rao et al., 1983). It is also being widely grown in Bangladesh and Myanmar suggesting its wide adaptability (Baisakh et al., 2001). Gayatri, a high yielding cultivar released from NRRI, is widely grown in shallow and medium low land ecology in Eastern India (Das, 2012). Samba Mahsuri (BPT, 5204) is one of the India's most popular and highly prized rice varieties because of its high yield 4.5 to $5.0 \mathrm{t} / \mathrm{ha}$ and excellent cooking quality (Reddi et al., 1979). Pooja, a high yielding cultivar released from National Rice Research Institute (NRRI), is widely grown in shallow and medium low land ecology in Eastern India (Das, 2012). Shabhagidhan is a popular variety suitable for upland, rainfed direct seeded as well as transplanted conditions. It is released for cultivation in state of Jharkhand and Odisha. It bears golden husked long bold grains and has an average productivity of 3.8-4.5 t/ha (Ravindra Babu et al., 2016). Tapaswini is an elite indica rice variety with a yield potential of 5.0 t/ha (Panda, 2000; Dokku et al., 2013). IR-64 is one of the mega rice varieties released by International Rice Research Institute (IRRI) in 1985 (Mackill \& Khush, 2018) and it is a prominent High Yielding Variety during the green revolution with a yield potential of $8 \mathrm{t} / \mathrm{ha}$ (Peng et al., 2000). Pusa Basmatil is highly popular because of its long slender grains and pleasant aroma. Cooked rice of Pusa Basmati 1 is endowed with desirable traits like soft texture and tenderness. It has a yield potential of $4.5 \mathrm{t} / \mathrm{ha}$ (Siddiq, 1990). It is extensively grown in the Basmati region of India. Basmati 370 is an aromatic variety and showed good tissue culture response (Raina et al., 1987).

Mature dehusked grains of the selected rice genotypes were washed with sterile distilled water and were surface sterilized successively with, $70 \%$ ethanol for two min, sodium hypochlorite (contains $4 \%(\mathrm{v} / \mathrm{v})$ active chlorine) for $15 \mathrm{~min}$ and with $0.1 \%(\mathrm{w} / \mathrm{v})$ aqueous mercuric chloride solution for $5 \mathrm{~min}$ with intermittent repeated washings with sterile distilled water (Vijayachandra et al., 1995).The kernels were inoculated in culture tubes containing semisolid callus induction (CI) medium MS (Murashige \& Skoog, 1962) supplemented with 2, 4-D (2.0 mg l. $\left.^{-1}\right)$ and $\mathrm{Kn}\left(0.5 \mathrm{mg} \mathrm{l}^{-1}\right)$ and were evaluated for their potential to support callus induction and subsequent green plant regeneration. Calli developed on these media were transferred onto MS regeneration medium supplemented with phytohormones [NAA $\left.\left(0.5 \mathrm{mg} \mathrm{l}^{-1}\right)+\mathrm{Kn}\left(0.5 \mathrm{mg} \mathrm{l}^{-1}\right)+\mathrm{BAP}\left(1.5 \mathrm{mg} \mathrm{l}^{-1}\right)\right]$. Callus induction (CI) and regeneration frequencies (RF) under the influence of additional nutrients and PGRs were recorded and statistical analyses were performed using SAS software (Chaitanya et al., 2013) in separate experiments.

\section{Results \& Discussion}

\subsection{Somatic Embryogenesis and Influence of Additional Nutrients}

The feasibility of induction of somatic embryogenesis in rice cultures was evaluated in selected rice varieties viz., Gayatri, Swarna, Samba Mahsuri, Pooja, Tapaswini and Sahabhagidhan. In Tapaswini, Swarna, Samba Mahsuri, Pooja and Gayatri, pre globular- pro embryos (PGPEs) were found in the embryogenic portion of the primary callus induced after 7-10 days on MS medium supplemented with 2, 4-D (2.0 $\left.\mathrm{mg} \mathrm{l}^{-1}\right)$ and $\mathrm{Kn}\left(0.5 \mathrm{mg} \mathrm{l}^{-1}\right)$. These structures could undergo subsequent developmental stages like complete globular, heart and torpedo shapes in subcultures. Moreover, somatic embryoids (SEs) were observed to be originating from the peripheral as well as deep-seated portions of the calli, but independent and free from the surrounding callus tissues.

However, when the embryogenic calli with these structures were sub cultured on fresh medium with $\left(2.0 \mathrm{mg} \mathrm{l}^{-1}\right)$ 2, 4-D, a major portion of the embryoids got dissipated to form callus. But, addition of L-Proline (500 $\left.\mathrm{mg} \mathrm{l}^{1^{-1}}\right)$ in the medium was observed to be better for long term maintenance of embryoids in culture. In Gayatri and Swarna, viable embryoids were observed even in 6-7 month old cultures (after 5-6 passages). Among the genotypes, highest frequency of somatic embryoids (both as \% calli with embryoids and number of SEs per unit callus $\sim 5 \mathrm{~mm}$ dia) was observed in Tapaswini closely followed by Swarna, Sambamahsuri, Pooja, Gayatri and Sahabhagidhan in that order (Table 1). Addition of L-Proline had positive and significant influence on somatic embryogenesis in all the genotypes. It is interesting to note 
that even though callus induction capabilities of Gayatri and Sahabhagidhan are low, they have good regeneration capabilities.

Table 1. Influence of additional nutrients on callus induction and regeneration of various cultivars

\begin{tabular}{|c|c|c|c|c|c|c|c|}
\hline \multirow{2}{*}{ S.No } & \multirow{2}{*}{ Genotypes } & & \multicolumn{5}{|c|}{ Frequency of calli with somatic embryoids (\%) } \\
\hline & & & $\mathrm{MS}_{\mathrm{K}}$ & $\mathrm{MS}_{\mathrm{C}}$ & $\mathrm{MS}_{\mathrm{P}}$ & $\mathrm{MS}_{0}$ & MSR \\
\hline \multirow{3}{*}{1} & \multirow{3}{*}{ Gayatri } & SEF & 48.34 & 58.7 & 53.9 & 16.8 & 62.93 \\
\hline & & SD & 2.114 & 1.11 & 1.35 & 2.35 & 2.31 \\
\hline & & SE & 1.21 & 0.64 & 0.78 & 1.36 & 1.33 \\
\hline \multirow{3}{*}{2} & \multirow{3}{*}{ Swarna } & SEF & 77.7 & 78.4 & 77.46 & 26.1 & 78.0 \\
\hline & & SD & 2.2 & 0.91 & 1.69 & 2.36 & 2.60 \\
\hline & & SE & 1.27 & 0.52 & 0.97 & 1.36 & 1.50 \\
\hline \multirow{3}{*}{3} & \multirow{3}{*}{ Samba Mahsuri } & SEF & 76.3 & 79.6 & 77.96 & 26.9 & 76.53 \\
\hline & & $\mathrm{SD}$ & 1.8 & 1.05 & 2.51 & 2.48 & 1.42 \\
\hline & & SE & 1.03 & 0.60 & 1.44 & 1.43 & 0.82 \\
\hline \multirow{3}{*}{4} & \multirow{3}{*}{ Pooja } & SEF & 72.23 & 75.7 & 75.76 & 22.43 & 72.63 \\
\hline & & SD & 2.159 & 1.05 & 1.81 & 2.07 & 2.47 \\
\hline & & SE & 1.24 & 0.60 & 1.04 & 1.20 & 1.43 \\
\hline \multirow{3}{*}{5} & \multirow{3}{*}{ Tapaswini } & SEF & 97.4 & 98.34 & 96.8 & 31.46 & 82.33 \\
\hline & & SD & 1.90 & 0.94 & 1.38 & 0.66 & 1.457 \\
\hline & & SE & 1.10 & 0.54 & 0.80 & 0.38 & 0.84 \\
\hline \multirow{3}{*}{6} & \multirow{3}{*}{ Sahabhagidhan } & SEF & 25.5 & 36.56 & 34.03 & 9.46 & 33.3 \\
\hline & & SD & 2.2 & 1.06 & 1.60 & 0.94 & 2.65 \\
\hline & & SE & 1.27 & 0.61 & 0.92 & 0.54 & 1.53 \\
\hline
\end{tabular}

SEF: Somatic embriod frequency; SD: Standard Deviation; SE: Standard Error. $\mathrm{MS}_{\mathrm{K}}=\mathrm{MS}+2,4-\mathrm{D}\left(2.0 \mathrm{mg} \mathrm{l}^{-1}\right)+$ $\mathrm{Kn}\left(0.5 \mathrm{mg} \mathrm{l}^{-1}\right) ; \mathrm{MS}_{\mathrm{P}}=\mathrm{MS}_{\mathrm{K}}+$ L-Proline $\left(500 \mathrm{mg} \mathrm{l}^{-1}\right) ; \mathrm{MS}_{\mathrm{C}}=\mathrm{MS}_{\mathrm{K}}+$ Casein hydrolysate $\left(300 \mathrm{mg} \mathrm{l}^{-1}\right) ; \mathrm{MS}_{\mathrm{O}}=$ Hormone free media: MSR $=$ MS basal salts + NAA $\left(0.5 \mathrm{mg} \mathrm{l}^{-1}\right)+\mathrm{kn}\left(0.5 \mathrm{mg} \mathrm{l}^{-1}\right)+\operatorname{BAP}\left(1.5 \mathrm{mg} \mathrm{l}^{-1}\right)$.

Addition of casein hydrolysate $\left(300 \mathrm{mgl}^{-1}\right)$ also had profound influence on the frequency of the calli with somatic embryoids and thereby average number of somatic embryoids per callus also increased. These somatic embryoids were observed in microscope and they varied in their morphology from genotype to genotype (Figure 1). Influence of casein hydrolysate on somatic embryogenesis is par with that of the L-Proline, but in case of Gayatri and Sahabhagidhan its influence was greater than that of L-Proline (Figure 2).

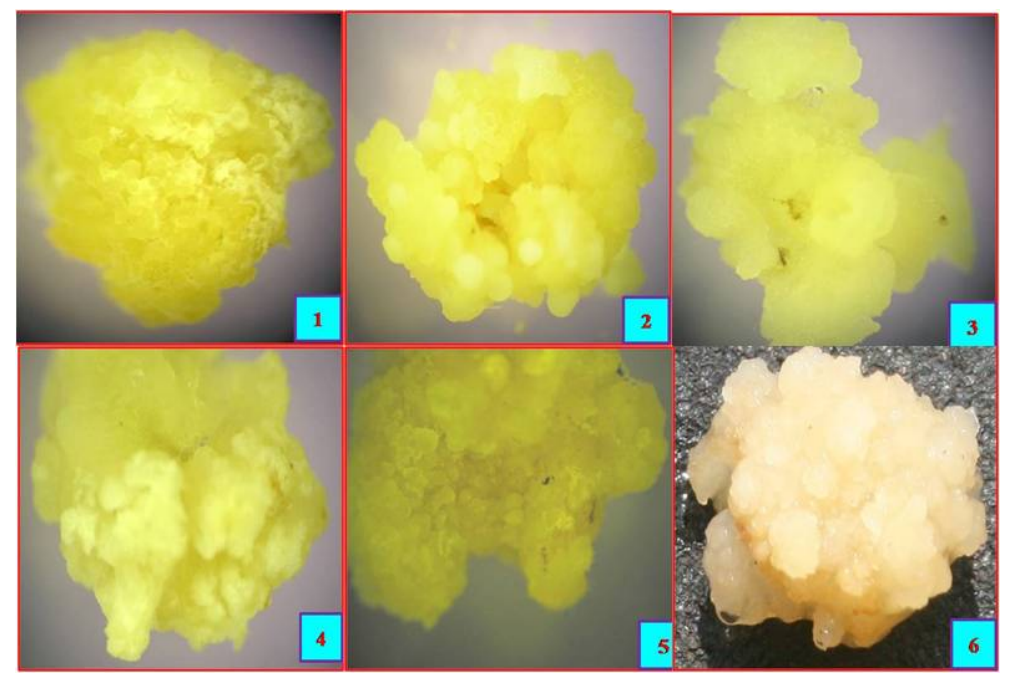

1) Pooja; 2) Gayatri; 3) Swarna; 4) IR-64; 5) Sahabhagidhan; 6) Tapaswini

Figure 1. Morphological shapes of callus of different genotypes 


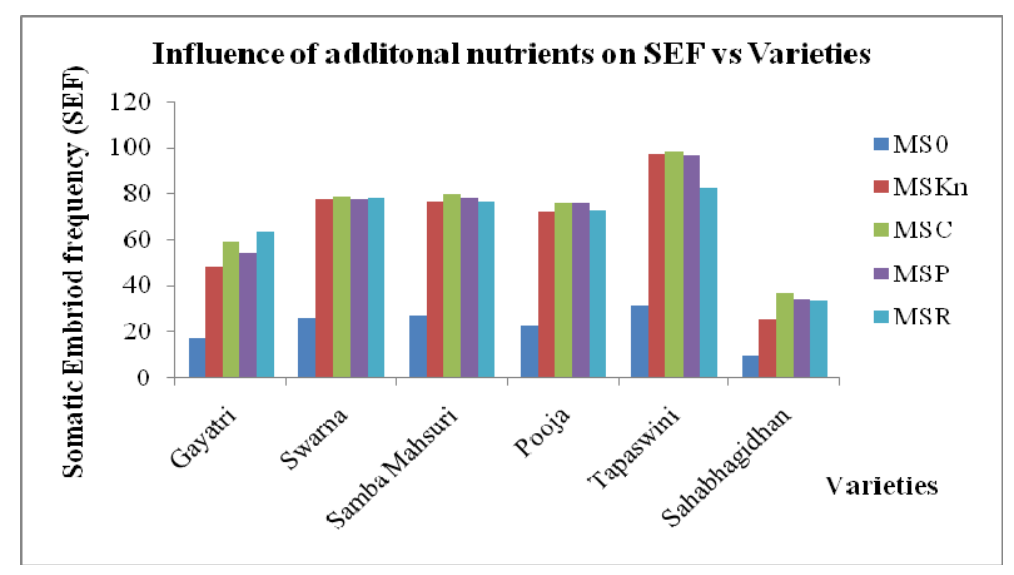

Figure 2. Influence of additional nutrients on somatic embriod frequency (SEF) during callus induction and regeneration in presence and absence of hormones in different cultivars

$\mathrm{MS}_{\mathrm{O}}=$ Hormone free media; $\mathrm{MS}_{\mathrm{Kn}}=\mathrm{MS}+2,4-\mathrm{D}\left(2.0 \mathrm{mg} \mathrm{l}^{-1}\right)+\mathrm{Kn}\left(0.5 \mathrm{mg} \mathrm{l}^{-1}\right) ; \mathrm{MS}_{\mathrm{C}}=\mathrm{MS}_{\mathrm{K}}+$ Casein hydrolysate $\left(300 \mathrm{mg} \mathrm{l}^{-1}\right) ; \mathrm{MS}_{\mathrm{P}}=\mathrm{MS}_{\mathrm{K}}+\mathrm{L}$-Proline $\left(500 \mathrm{mg} \mathrm{l}^{-1}\right) ; \mathrm{MSR}=\mathrm{MS}$ basal salts $+\mathrm{NAA}\left(0.5 \mathrm{mg} \mathrm{l}^{-1}\right)+\mathrm{kn}\left(0.5 \mathrm{mg} \mathrm{l}^{-1}\right)+\mathrm{BAP}$ $\left(1.5 \mathrm{mg} \mathrm{l}^{-1}\right)$;

The analysis of variance of the data suggests that significant differences exist between treatments, genotypes and also interaction between genotypes and the treatments (Table $2(a, b)$ ).

Table 2. Anova on formation of somatic embryoids in different genotypes with the influence of additional nutrients on:

\begin{tabular}{|c|c|c|c|c|c|}
\hline \multicolumn{6}{|c|}{ a. Somatic embryoid formation } \\
\hline Source of Variation & $\%$ of total variation & P value & P value summary & Significant? & \\
\hline Interaction & 0.7612 & $<0.0001$ & $* * * *$ & Yes & \\
\hline Media & 0.9464 & $<0.0001$ & $* * * *$ & Yes & \\
\hline Varieties & 97.87 & $<0.0001$ & $* * * *$ & Yes & \\
\hline ANOVA table & SS & $\mathrm{DF}$ & MS & $\mathrm{F}(\mathrm{DFn}, \mathrm{DFd})$ & $P$ value \\
\hline Interaction & 182.3 & 10 & 18.23 & $F(10,36)=6.459$ & $\mathrm{P}<0.0001$ \\
\hline Media & 226.7 & 2 & 113.4 & $F(2,36)=40.15$ & $\mathrm{P}<0.0001$ \\
\hline Varieties & 23443 & 5 & 4689 & $F(5,36)=1661$ & $\mathrm{P}<0.0001$ \\
\hline Residual & 101.6 & 36 & 2.823 & & \\
\hline
\end{tabular}

MS: Mean square; SS: Sum-of-squares; df: degrees of freedom

\begin{tabular}{llllll}
\hline \multicolumn{6}{c}{ b. Regeneration } \\
\hline Source of Variation & $\%$ of total variation & P value & P value summary & Significant? & \\
Interaction & 3.546 & $<0.0001$ & $* * * *$ & Yes & \\
Media & 75.78 & $<0.0001$ & $* * * *$ & Yes & \\
Varieties & 20.24 & $<0.0001$ & $* * * *$ & Yes & \\
ANOVA table & SS & DF & MS & F (DFn, DFd) & P value \\
Interaction & 869.4 & 5 & 173.9 & $\mathrm{~F}(5,24)=39.76$ & $\mathrm{P}<0.0001$ \\
Media & 18582 & 1 & 18582 & $\mathrm{~F}(1,24)=4248$ & $\mathrm{P}<0.0001$ \\
Varieties & 4964 & 5 & 992.8 & $\mathrm{~F}(5,24)=227.0$ & $\mathrm{P}<0.0001$ \\
Residual & 105.0 & 24 & 4.374 & & \\
\hline
\end{tabular}

\subsection{Influence of Additional Nutrients on Callus Induction Rate}

Attempts were made to study the influence of additional supplements on callus induction frequencies, in addition to the constituents of the MS medium. Use of casein hydrolysate was found to be beneficial for generation of embryogenic calli in japonica (Hiei et al., 1994; Toki, 1997) as well as in indica rice varieties (Zhang et al., 1996). 
Combination of eighteen amino acids present in casein hydrolysate was able to substitute nitrogen source for the growth of embryos (Verbruggen \& Hermans, 2008). CH is also a rich source of vitamins, calcium, phosphate, and several microelements and helps in maintaining the cell for longer period (Siripornadulsil et al., 2002). A specimen analysis of the casein hydrolysate published by the manufacturers indicates that the quantity of nitrogen supplied by $400 \mathrm{mgl}^{-1}$ of casein hydrolysate was equivalent to that supplied by $2.0 \mathrm{mM}$ sodium nitrate. Gorham (1950) showed that casein hydrolysate was effective as a nitrogen source for the growth of Lemna minor in dark. In the present study, casein hydrolysate $\left(300 \mathrm{mgl}^{-1}\right)$ was tested at callus induction level and the results suggest a positive role of casein hydrolysate on enhancement of callus growth both qualitatively and quantitatively. The results recommend the usage of casein hydrolysate essentially for callus induction as it plays a pivotal role in providing additional nitrogen source to the calli and helps in growth of cells.

L-Proline is an important amino acid used for enhancement of somatic embryogenesis and callus growth in rice. Proline induced stimulation of somatic embryogenesis has been well documented in plant systems like rice, maize, cat grass and other crop plants (Shetty \& McKersie, 1993; Afsharsterle et al., 1996; Suprasanna et al., 1997; Murch et al., 1999; Siripornadulsil et al., 2002). The use of proline in the medium has been reported to be effective for the initiation and maintenance of embryogenic calli (Datta et al., 1992; Kishor et al., 1999). Keeping in view of the suggested role of proline and its analogs in stimulating auxin induced embryogenesis; in the present study, L-Proline $\left(\mathrm{gg}^{-1}\right)$ was supplemented to the media used for callus induction and the results suggest the induction of good quality callus (Table 1). Shetty \& McKersie (1993) found that proline and thioproline significantly contributed to enhanced embryogenic response (embryogenic callus development and somatic embryos). It is opined that alterations in proline metabolism and its potential regulation of associated purine metabolism are important in directing cell differentiation i.e., auxin-induced somatic embryogenesis. Amino acids play a crucial role as organic sources of nitrogen during invitro growth and development of plant cells. They are readily available and assimilated at a faster rate than the inorganic sources of nitrogen. L-Proline acts as organic source of nitrogen. The observations of the study recommend the use of proline in the media as an essential requirement to provide nitrogen source as well as to maintain osmotic balance in the cells.

\subsection{Influence of Gelling Agents on Callus Induction and Regeneration}

An experiment was conducted with the objective of enhancing the rates of regeneration in indica rice varieties. Here, four different gelling agents viz., agar, gelrite, clarigel and phytagel were evaluated in both callus induction and regeneration steps using the following rice genotypes viz., Swarna, Gayatri, Sambamahsuri, IR-64, Pusa Basmati 1 and Basmati 370. All the four gelling agents support callus induction but the frequency is high with gelrite closely followed by clarigel, agar and phytagel, in that order, (Table 3) irrespective of the cultivar (Figure $3)$.

The analysis of variance of the data suggest that significant differences exist between treatments and varieties with no interaction between genotypes and treatments for callus induction with various gelling agents (Table 4).

Of the four gelling agents evaluated for their influence on regeneration, the frequency is high on agar followed by gelrite, clarigel and phytagel in that order (Table 5) (Figure 4). The analysis of variance data suggests that differences in regeneration rates are significant between the treatments (different gelling agents) while the differences were not significant between different genotypes evaluated (Table 6).

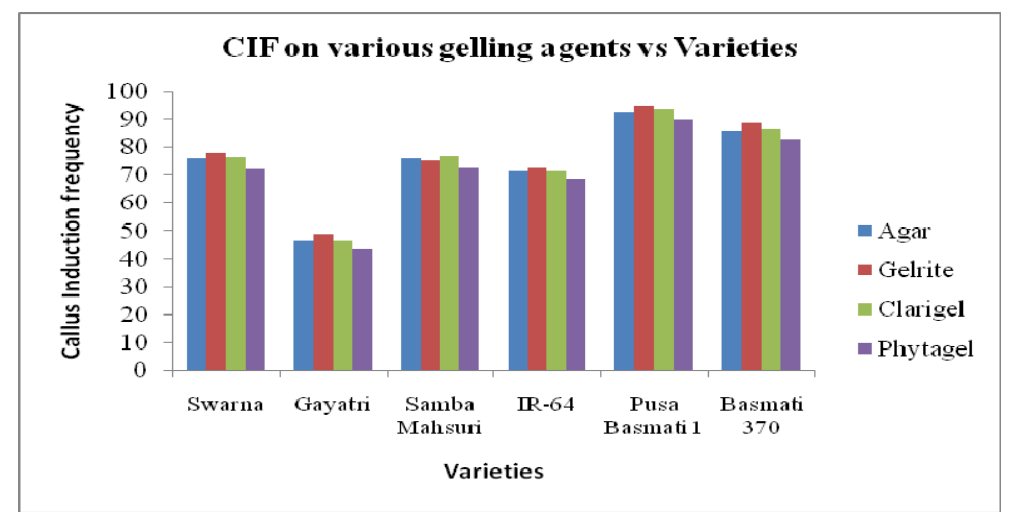

Figure 3. Influence of various gelling agents on Callus Induction frequency (CIF) 
Table 3. Callus induction frequencies on various gelling agents

\begin{tabular}{|c|c|c|c|c|c|c|}
\hline \multirow{2}{*}{ S.N } & \multirow{2}{*}{ Genotype } & & \multicolumn{4}{|c|}{ Callus induction frequency (CIF) } \\
\hline & & & Agar & Gelrite & Clarigel & Phytagel \\
\hline \multirow{3}{*}{1} & \multirow{3}{*}{ Swarna } & CIF & 75.6 & 77.6 & 76.37 & 72.37 \\
\hline & & SD & 2.10 & 1.05 & 2.80 & 1.96 \\
\hline & & SE & 1.21 & 0.60 & 1.61 & 1.131 \\
\hline \multirow{3}{*}{2} & \multirow{3}{*}{ Gayatri } & $\mathrm{CIF}$ & 46.36 & 48.64 & 46.5 & 43.74 \\
\hline & & SD & 2.20 & 0.75 & 3.3 & 1.95 \\
\hline & & SE & 1.27 & 0.43 & 1.90 & 1.12 \\
\hline \multirow{3}{*}{3} & \multirow{3}{*}{ Samba Mahsuri } & $\mathrm{CIF}$ & 75.64 & 75.37 & 76.4 & 72.5 \\
\hline & & SD & 2.11 & 0.85 & 2.90 & 1.75 \\
\hline & & $\mathrm{SE}$ & 1.22 & 0.49 & 1.67 & 1.01 \\
\hline \multirow{3}{*}{4} & \multirow{3}{*}{ IR-64 } & $\mathrm{CIF}$ & 71.56 & 72.53 & 71.47 & 68.6 \\
\hline & & SD & 2.05 & 0.94 & 2.70 & 2.2 \\
\hline & & $\mathrm{SE}$ & 1.18 & 0.54 & 1.56 & 1.27 \\
\hline \multirow{3}{*}{5} & \multirow{3}{*}{ Pusa Basmati 1} & $\mathrm{CIF}$ & 92.54 & 94.53 & 93.5 & 89.66 \\
\hline & & SD & 1.70 & 1.30 & 3.16 & 2.25 \\
\hline & & SE & 0.98 & 0.75 & 1.82 & 1.30 \\
\hline \multirow{3}{*}{6} & \multirow{3}{*}{ Basmati 370} & $\mathrm{CIF}$ & 85.67 & 88.36 & 86.47 & 82.4 \\
\hline & & SD & 2.11 & 0.80 & 3.30 & 1.67 \\
\hline & & $\mathrm{SE}$ & 1.21 & 0.46 & 1.90 & 0.96 \\
\hline
\end{tabular}

CIF: Callus induction frequency; SD: Standard Deviation; SE: Standard Error

Table 4. Anova of callus induction data with different gelling agents

\begin{tabular}{llllll}
\hline Source of Variation & \% of total variation & P value & P value summary & Significant? \\
\hline Interaction & 0.1010 & 0.9984 & $\mathrm{~ns}$ & No \\
Solidifiers & 1.367 & $<0.0001$ & $* * * *$ & Yes & Yes \\
Varieties & 97.12 & $<0.0001$ & $* * * *$ & $\mathrm{~F}$ (DFn, DFd) & $\mathrm{P}$ value \\
ANOVA table & $\mathrm{SS}$ & $\mathrm{DF}$ & $\mathrm{MS}$ & $\mathrm{F}(15,48)=0.2291$ & $\mathrm{P}=0.9984$ \\
Interaction & 15.73 & 15 & 1.048 & $\mathrm{~F}(3,48)=15.50$ & $\mathrm{P}<0.0001$ \\
Solidifiers & 212.8 & 3 & 70.94 & $\mathrm{~F}(5,48)=660.8$ & $\mathrm{P}<0.0001$ \\
Varieties & 15120 & 5 & 3024 & & \\
Residual & 219.7 & 48 & 4.576 & & \\
\hline
\end{tabular}

MS: Mean square; SS: Sum-of-squares; df: degrees of freedom

Table 5. Regeneration frequencies of cultivars on various gelling agents

\begin{tabular}{|c|c|c|c|c|c|c|}
\hline \multirow{2}{*}{ S.No } & \multirow{2}{*}{ Genotype } & & \multicolumn{4}{|c|}{ Regeneration frequency (REF) } \\
\hline & & & Agar & Gelrite & Clarigel & Phytagel \\
\hline \multirow{3}{*}{1} & \multirow{3}{*}{ Swarna } & REF & 64.57 & 63.87 & 62.5 & 62.4 \\
\hline & & $\mathrm{SD}$ & 6.30 & 4.43 & 4.25 & 2.76 \\
\hline & & SE & 3.63 & 2.56 & 2.45 & 1.59 \\
\hline \multirow{3}{*}{2} & \multirow{3}{*}{ Gayatri } & REF & 79.44 & 76.57 & 75.54 & 75.4 \\
\hline & & $\mathrm{SD}$ & 4.70 & 5.30 & 3.70 & 3.10 \\
\hline & & SE & 2.71 & 3.06 & 2.14 & 1.79 \\
\hline \multirow{3}{*}{3} & \multirow{3}{*}{ Samba Mahsuri } & REF & 46.47 & 45.73 & 45.34 & 45.4 \\
\hline & & $\mathrm{SD}$ & 4.16 & 4.90 & 4.15 & 3.40 \\
\hline & & SE & 2.40 & 2.82 & 2.39 & 1.96 \\
\hline \multirow{3}{*}{4} & \multirow{3}{*}{ IR-64 } & REF & 42.0 & 41.47 & 41.67 & 48 \\
\hline & & $\mathrm{SD}$ & 3 & 4.90 & 4.152 & 8.92 \\
\hline & & SE & 1.73 & 2.83 & 2.39 & 5.15 \\
\hline \multirow{3}{*}{5} & \multirow{3}{*}{ Pusa Basmati 1} & REF & 84.5 & 82.37 & 81.4 & 81.57 \\
\hline & & $\mathrm{SD}$ & 2.30 & 5.15 & 3.91 & 3.25 \\
\hline & & SE & 1.33 & 2.97 & 2.26 & 1.87 \\
\hline \multirow{3}{*}{6} & \multirow{3}{*}{ Basmati 370} & REF & 75 & 74.5 & 71.53 & 74.53 \\
\hline & & $\mathrm{SD}$ & 1 & 5.3 & 2.42 & 2.81 \\
\hline & & SE & 0.57 & 3.06 & 1.39 & 1.62 \\
\hline
\end{tabular}

REF: Regeneration frequency; SD: Standard Deviation; SE: Standard Error 
Table 6. Anova of regeneration data with different gelling agents

\begin{tabular}{llllll}
\hline Source of Variation & \% of total variation & P value & P value summary & Significant? \\
\hline Interaction & 0.7055 & 0.9623 & $\mathrm{~ns}$ & No \\
Solidifiers & 0.2944 & 0.4507 & $\mathrm{~ns}$ & No & Yes \\
Varieties & 93.74 & $<0.0001$ & $* * * *$ & $\mathrm{~F}(\mathrm{DFn}, \mathrm{DFd})$ & $\mathrm{P}$ value \\
ANOVA table & $\mathrm{SS}$ & $\mathrm{DF}$ & $\mathrm{MS}$ & $\mathrm{F}(15,48)=0.4289$ & $\mathrm{P}=0.9623$ \\
Interaction & 123.2 & 15 & 8.211 & $\mathrm{~F}(3,48)=0.8948$ & $\mathrm{P}=0.4507$ \\
Solidifiers & 51.40 & 3 & 17.13 & $\mathrm{~F}(5,48)=170.9$ & $\mathrm{P}<0.0001$ \\
Varieties & 16364 & 5 & 3273 & & \\
Residual & 919.0 & 48 & 19.15 & &
\end{tabular}

MS: Mean square; SS: Sum-of-squares; df: degrees of freedom

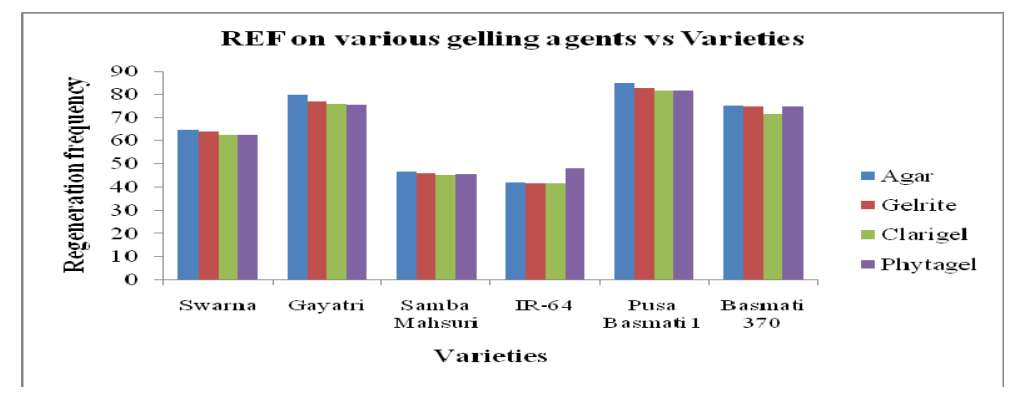

Figure 4. Influence of various gelling agents on Regeneration frequency (REF)

\section{Influence of Gelling Agents}

Agar is extracted from the seaweed Gelidium and it forms a good support for media (Armisen \& Gaiatas, 2009). Commercially available gelling materials like clarigel (Hi-media) and gelrite (Sigma-Aldrich) are also good for callus induction and especially gelrite forms a clear and transparent media which is helpful in clearly identifying the newly emerging callus. Importance of media being transparent is more conspicuous while working with very small explants like immature embryos, anthers and embryogenic calli especially during transformation experiments using gene gun etc.

Gellan gum is a widely used gelling agent in plant tissue culture (Puchooa et al., 1999) that is marketed under various trade names including Gelrite, Phytagel and Kelcogel. It is an exo polysaccharide that encapsulates cells of the bacterium Sphingomonas paucimobilis and Pseudomonas elodea, from which it is obtained by industrial fermentation. The structure, physico-chemical properties and the rheology of solutions of gellan gum and related polysaccharides has been reviewed by Banik et al. (2000). Gellan gum consists of a linear repeating tetra saccharide of D-glucose, D-glucuronic acid, D-glucose and L-rhamnose.

An important aspect here to note is that plants regenerate well and produce intense roots only when the gelling agent is added in proper concentrations and it is found in the study (Table 5) that plants regenerate well when traditional agar is used rather than the commercial gelling agents in contrast to callus induction. In our experiments, a concentration of $10 \mathrm{gl}^{-1}$ of agar for callus induction and $9 \mathrm{gl}^{-1}$ for regeneration and $8 \mathrm{gl}^{-1}$ for rooting media, were used so as to create a porous environment for different stages but in comparison, only $2.6 \mathrm{gl}^{-1}$ of gelrite would be sufficient for callus induction and regeneration. High concentration of gelling agent was found to improve plantlet regeneration in this study, which corroborates the findings of earlier reports in rice (Jain et al., 1996; Khaleda \& Al-Forkan, 2006). Recently plant derived phytagels are also available as gelling agents. Earlier it was reported (Suprasanna et al., 2000) that the same gelling agent at various concentrations have profound influence in retention of water and regulation of moisture regime of the medium and for this reason, addition of agar in correct proportions is needed to meet the requirements at different stages of culture i.e. callus induction, regeneration and rooting of plantlets generated in tissue culture.

Transformation experiments require the addition of antibiotics to the media for selection and here it is found that some commercial gelling agents do not support the dissolution of some antibiotics, in such case use of traditional agar would be ideal choice as a gelling agent.

\section{Acknowledgements}


The authors are thankful to Director, NRRI for the facilities and encouragement. The authors Sai Krishna Repalli and Chaitanya Kumar Geda are thankful to ICAR (NPTC) for providing them Fellowship.

\section{Conflict of interests}

The authors declare that there is no conflict of interests regarding publication of this paper.

\section{References}

Abiri, R., Valdiani, A., Maziah, M., Shaharuddin, N. A., ..., \& Talei, D. (2015). A critical review of the concept of transgenic plants: Insights into pharmaceutical biotechnology and molecular farming. Curr Issues Mol Biol, 18, 21-42.

Afolabi, A. S., Oyebanji, O., Odusanya, O., Abo, M. E., Misra, M., \& Ogbadu, G. H. (2008). Regeneration of plants from rice caryopsis derived callus culture of Nigerian local cv. Suakoko 8 and a NERICA cv. FARO 55. African J. Plant Sci., 2, 109-112.

Afsharsterle, S., Pang, E. C. K., Brown, J. S., \& Kollmorgen, J. E. (1996). Embryogenic callus induction and plant regeneration in Triticum tauschii, the diploid D-genome donor for bread wheat (Triticumaestivum). Australian Journal of Botany, 44, 489-497.

Aldemita, R. R., \& Hodges, T. K. (1996). Agrobacterium tumefaciens mediated transformation of japonica and indica varieties. Planta, 199, 612-617.

Armisen, R., \& Gaiatas, F. (2009). Agar in: Handbook of Hydrocolloids (Second edition) Woodhead Publishing Series in Food Science, Technology and Nutrition (pp. 82-107).

Azizi, P., Rafii, M. Y., Mahmood, M., Hanafi, M. M., ..., \& Sahebi, M. (2015). Highly efficient protocol for callogenesis, somagenesis and regeneration of Indica rice plants. C R Biol, 338, 463-470.

Baisakh, N., Datta, K., Oliva, N., Ona, I., Rao, G. J. N., Mew, T. W., \& Datta, S. K. (2001). Rapid development of homozygous transgenic rice using anther culture harboring rice chitinase gene for enhanced sheath blight resistance. Plant Biotechnology, 18, 101-108.

Banik, R. M., Kanary, B., \& Upadhyay, S. N. (2000). Exopolysaccharide of the gellan family prospects and potential review. World Journal of Microbiology and Biotechnology, 16(5), 407-414.

Benlioglu, B., Tuna, D., Birsin, M., \& Ozgen, A. (2015). Effect of growth regulators on tissue culture parameters in rice (Oryza sativa L.). Ekin J Crop Breed and Gen, 2, 43-46.

Chaitanya, K. G., Sai Krishna, R., Mohan Dev, T., \& Rao, G. J. N. (2013). Genetic variation in in vitro response of elite aromatic and non-aromatic rice varieties. Oryza, 50(4), 329-333.

Che Radziah, C., Siti Nurkhalida, A., Zamri, Z., \& Ismanizan, I. (2012). Effect of illumination, casein hydrolysate and proline on callus induction of Oryza sativa L. var. MR219. Malays Appl Biol, 41, 37-41.

Cho, M. J., Yano, H., Kim, H. K., Jung, H. R., ..., \& Lemaux, P. G. (2004). Stable transformation of rice (Oryza sativa L.) via micro projectile bombardment of highly regenerative, green tissues derived from mature seed. Plant Cell Reports, 22, 483-489.

Dahot, M. U. (2007). Morpho-physiological aspects of micro-propagating banana under different hormonal conditions. Asian J Plant Sci, 6, 496-501.

Das, S. R. (2012). Rice in Odisha (p. 31). IRRI Technical Bulletin No. 16. Los Baños (Philippines): International Rice Research Institute.

Datta. (1992). Efficient fertile plant regeneration from protoplast of indica rice breeding line IR72 (Oryza sativa L.). Plant Cell Reports, 11, 229-233.

Din, A. R. J. M., Ahmad, F. I., Wagiran, A., Samad, A. A., Rahmat, Z., \& Sarmidi, M. R. (2016). Improvement of efficient in vitro regeneration potential of mature callus induced from Malaysian upland rice seed (Oryza sativa cv. Panderas). Saudi J Biol Sci, 23, S69-S77.

Dokku, P., Das, K. M., \& Rao, G. J. N. (2013). Pyramiding of four resistance genes of bacterial blight in Tapaswini, an elite rice cultivar, through marker-assisted selection. Euphytica, 192, 87-96.

Gorham, P. R. (1950). Heterotrophic nutrition of seed plants with particular reference to Lemna minor L. Canadian Journal of Research sec. C, 28, 356. 
Haque, M. S., Wada, T., \& Hattori, K. (2003). Effects of sucrose, mannitol and KHsub2/subPOsub4/sub on proliferation of root tip derived shoots and subsequent bulblet formation in garlic. Asian J Plant Sci, 2, 903-908.

Hiei, Y., Ohta, S., Komari, T., \& Kumashiro, T. (1994). Efficient transformation of rice (Oryza sativa L.) mediated by Agrobacterium and sequence analysis of the boundaries of the T-DNA. The Plant Journal, 6, 271-282.

Ikeuchi, M., Sugimoto, K., \& Iwase, A. (2013). Plant callus: Mechanisms of induction and repression. Plant Cell, 25, 3159-3173.

Islam, M. M., Ahmed, M., \& Mahaldar, D. (2005). In vitro callus induction and plant regeneration in seed explants of rice (Oryza Sativa L.). Res J Agric Biol Sci, 1, 72-75.

Islam, M. M., Roly, Z. Y., Lee, Y., \& Khalekuzzaman, M. (2014). In vitro propagation and genetic transformation system using immature embryo in elite rice (Oryza sativa L.) cultivars. Plant Breed Biotechnol, 2, 88-96.

Jain, R. K., Jain, S., \& Wu, R. (1996). Stimulatory effect of water stress on plant regeneration in aromatic indica rice varieties. Plant cell Reports, 15, 449-454.

Khaleda, L., \& Al-Forkan, M. (2006). Genotypic variability in callus induction and plant regeneration through somatic embryogenesis of five deepwater rice (Oryza sativa L.) cultivars of Bangladesh. Afr J Biotechnol, $17,5-16$.

Khanna, H. K., \& Raina, S. K. (2002). Elite Indica transgenic rice plants expressing modified Cry1Ac endotoxins of Bacillus thuringiensis show enhanced resistance to yellow stemborer (Scirpophaga incertulas). Transgenic Research, 11, 411-423.

Khelada, L., \& Al-Forkan. (2006). Genotypic variability in callus induction and plant regeneration through somatic embryogenesis of five deep water rice (Oryza sativa L.) cultivars of Bangladesh. African Journal of Biotechnology, 5(16), 1435-1440.

Kishor, P. B. K., Sangam, S., \& Naidu, K. P. (1999). Sodium, potassium, sugar, alcohol and proline mediated somatic embryogenesis and plant regeneration in recalcitrant rice callus (pp. 78-85). In: Plant Tissue Culture and Biotechnology: Emerging Trends Proceedings of the symposium held at Hyderabad, India.

Lin, Y. J., \& Zhang, Q. (2005). Optimising the tissue culture conditions for high efficiency transformation of indica rice. Plant Cell Rep, 23, 540-547.

Mackill, \& Khush. (2018). IR64: A high-quality and high-yielding mega variety. Rice, 11, 18.

Murashige, T., \& Skoog, F. (1962). A revised medium for rapid growth and bioassays with tobacco tissue cultures. Plant Physiology, 15, 473-497.

Murch, S. J., Victor, J. M. R., Krishnaraj, S., \& Saxena, P. K. (1999). The role of proline in thidiazuron-induced somatic embryogenesis in peanut. In Vitro Cellular \& Developmental Biology-Plant, 35(1), 102-105.

Ngomuo, M., \& Ndakidemi, P. (2013). The effects of auxins and cytokinin on growth and development of (Musa sp.) var. "Yangambi" explants in tissue culture. American. J Plant Sci, 4, 2174.

Panda, A. R. (2000). Growing Rice Variety Tapaswini. Technical Bulliten, CRRI Cuttack, Odisha.

Pawar, B., Prashant, K., Bahurupe, J., Jadhav, A., Anil, K., \& Pawar, S. (2015). Proline and Glutamine Improve in vitro Callus Induction and Subsequent Shooting in Rice. Rice Sci, 22, 283-289.

Peng, S., Laza, R. C., Visperas, R. M., Sanico, A. L., Cassman, K. G., \& Khush, G. S. (2000). Grain yield of rice cultivars and lines developed in the Philippines since 1966. Crop Sci, 40, 307-314.

Puchooa, D., Purseramen, P. N., \& Rujbally, B. R (1999). Effects of medium support and gelling agent in the tissue culture of tobacco (Nicotiana tabacum). Sci Tech Res J, 3, 129-144.

Raina, S. K., Sathish, P., \& Sarma, K. S. (1987). Plant regeneration from In vitro cultures of anthers and mature seeds of rice (Oryza sativa L.) cv. Basmati-370. J. Plant Cell Rep., 6, 43-45.

Rao, V. R., Reddy, P. S., Murthy, N., Rao, I., Rao, P. S., Rao, C. B., \& Rao, G. M. (1983). Swarna (MTU 7029)-a new stable hybrid with wide adaptation. Oryza, 20, 240-242. 
Ravindra Babu, V., Padmavathi, Ch., Neeraja, C. N., Krishnaveni, D., ..., \& Chaitanya, U. (2016). 50 years of AICRIP...Way forward (p. 292). Technical Bulletin No. 92/2016. ICAR-Indian Institute of Rice Research, Rajendranagar, Hyderabad-500 030, Telangana State, India.

Reddi, M. V., Prasad, S. S. N. D. B., Reddy, B. M., \& Rao, L. V. S. (1979). BPT 5204: A new rice variety for kharif season for coastal districts of Andhra Pradesh. Andhra Agriculture Journal, 26, 66-67.

Repalli, S. K., Ananata, M. B., \& Prasanta, K. D. (2018). In vitro responses of ten indica rice genotypes for callus induction. Ann. Agric. Res. New Series, 39(1), 26-31.

Saharan, V., Yadav, R. C., Yadav, N. R., \& Chapagain, B. P. (2004). High frequency plant regeneration from desiccated calli of indica rice (Oryza sativa L.). Afr J Biotechnol, 3, 256-259.

Shetty, K., \& McKersie, B. D. (1993). Proline, thioproline, and potassium mediated stimulation of somatic embryogenesis in alfalfa (Medicago sativa L.). Plant Science, 88, 185-193.

Siddiq, E. A. (1990). Export prospects of Indian Basmati Rices. Indian Farming, 40, 45-47.

Siripornadulsil, S., Traina, S., Verma, D. P. S., \& Sayre, R. T. (2002). Molecular mechanisms of proline-mediated tolerance to toxic heavy metals in transgenic microalgae. Plant Cell, 14, 2837-2847.

Sivanesan, I., \& Park, S. W. (2014). The role of silicon in plant tissue culture. Front Plant Sci, 5, 571.

Suprasanna, P., Rao, K. V., \& Reddy, G. M. (1997). Embryogenic callus in maize: Genotypic and amino acid effects. Cereal Research Communication, 22(1-2), 79-82.

Suprasanna, S., Ganapathi, T. R., \& Rao, P. A. (2000). High frequency plant regeneration from somatic embryos of indica rice. Rice Genetics Newsletter, 1, 183.

Szabados, L., \& Savoure, A. (2010). Proline: A multifunctional amino acid. Trends Plant Sci, 15, 89-97.

Thokozani, B. L., Zulu, D., Sileshi, C., Teklehaimanot, Z., Gondwe, D. S., Sarasan, V., \& Stevenson, P. (2013). Seed germination and in vitro regeneration of the African medicinal and pesticidal plant, Bobgunnia madagascariensis. Afr J Biotechnol, 10, 5959-5966.

Toki, S. (1997). Rapid and efficient Agrobacterium-mediated transformation in rice. Plant Mol Biol Reporter, 15(1), 16-21.

Verbruggen, N., \& Hermans, C. (2008). Proline Accumulation in Plants: A Review. Amino Acids, 35, 753-759.

Vijayachandra, K., Palanichelvam, K., \& Veluthambi, K. (1995). Rice scutellum induces Agrobacterium tumefaciens vir genes and T-strand generation. Plant Molecular Biology, 29, 125-133.

Visarada, K., \& Sarma, N. (2002). Qualitative assessment of tissue culture parameters useful in transformation of indica rice. Curr Sci, 82, 343-346.

Yaseen, M., Ahmad, T., Sablok, G., Standardi, A., \& Hafiz, I. A. (2013). Review: Role of carbon sources for in vitro plant growth and development. Mol Biol Rep, 40, 2837-2849.

Yinxia, Z., \& Te-chato, S. (2012). Callus induction and plantlet regeneration from mature embryos of indica rice (Oryza Sativa L.) cultivar Kra Dang Ngah. J AgricTech, 8, 2423-2433.

Zaidi, M. A., Narayanan, M., Sardana, R., Taga, I., ..., \& Altosaar, I. (2006).Optimizing tissue culture media for efficient transformation of different indica rice genotypes. Agron. Res., 4, 563-575.

Zhang, S., Chen, L., Qu, R., Marmey, P., Beachy, R. N., \& Fauquet, C. M. (1996). Regeneration of fertile transgenic indica (group 1) rice plants following microprojectile transformation of embryogenic suspension culture cells. Plant Cell Reports, 15, 465-469.

Zuraida, A., Rahiniza, K., Nurul Hafiza, M., Roowi, S., Zamri, Z., \& Subramaniam, S. (2010). Factors affecting delivery and transient expression of gusA gene in Malaysian indica rice MR 219 callus via biolistic gun system. Afr J Biotechnol, 9, 8810.

\section{Copyrights}

Copyright for this article is retained by the author(s), with first publication rights granted to the journal.

This is an open-access article distributed under the terms and conditions of the Creative Commons Attribution license (http://creativecommons.org/licenses/by/4.0/). 